Original Article

\title{
IN VITRO ANTIPLASMODIAL AND CYTOTOXIC ACTIVITIES OF A SUNGKAI (PERONEMA CANESCENS) LEAF EXTRACT
}

\author{
JHONS FATRIYADI SUWANDI ${ }^{*}$, MAHARDIKA AGUS WIJAYANTI ${ }^{2}$, MUSTOFA ${ }^{3}$
}

1Department of Microbiology and Parasitology, Faculty of Medicine, University of Lampung, Bandar Lampung, Indonesia, ${ }^{2}$ Department of Parasitology, Faculty of Medicine, Public Health and Nursing, Gadjah Mada University, Yogyakarta, Indonesia, ${ }^{3}$ Department of Pharmacology and Therapy, Faculty of Medicine, Public Health and Nursing, Gadjah Mada University, Yogyakarta, Indonesia Email: yadisuwandi04@gmail.com

Received: 03 Fab 2018 Revised and Accepted: 07 Sep 2018

\section{ABSTRACT}

Objective: The aim of this study was to assess the antiplasmodial and cytotoxic activities and to evaluate the selectivity indices of acetone, ethanol and aqueous extracts of Peronema canescens leaves.

Methods: Antiplasmodial activity was measured in vitro against Plasmodium falciparum strains D10 and FCR3 by $72 \mathrm{~h}$ incubation at $37{ }^{\circ} \mathrm{C}$ in a candle jar. Parasitaemia was calculated by counting the parasite numbers in thin smears. In vitro cytotoxicity was assayed in Vero cells using 3-(4,5dimethylthiazol-2-yl)-2,5-diphenyltetrazolium bromide (MTT) and reading the absorbency at $595 \mathrm{~nm}$ with an ELISA reader. The assessed parameters included: $50 \%$ inhibitory concentration $\left(\mathrm{IC}_{50}\right)$ of antiplasmodial activity, $\mathrm{IC}_{50}$ of cytotoxic activity and the selectivity index of the Peronema canescens leaf extract.

Results: The IC ${ }_{50}$ values for the acetone, ethanol and aqueous extracts were $26.33 \pm 1.65,37.96 \pm 8.17$ and $12.26 \pm 1.05 \mu \mathrm{g} / \mathrm{ml}$, respectively, against the Plasmodium falciparum D10 strain and 51.14 $\pm 8.65,70.22 \pm 14.13$ and $34.85 \pm 6.04 \mu \mathrm{g} / \mathrm{ml}$, respectively, against the FCR3 strain. For Vero cells, the IC 50 values for the acetone, ethanol and aqueous extracts were $23.37 \pm 5.63,629.46 \pm 24.85$ and $634.00 \pm 144.82 \mu \mathrm{g} / \mathrm{ml}$, respectively. The selectivity indices of these extracts were $0.89,16.46$ and 51.70 , respectively, for the D10 strain and $0.46,8.90$ and 18.00, respectively, for the FCR3 strain.

Conclusion: The aqueous extract of Peronema canescens leaves had the highest in vitro antiplasmodial activity and the best selectivity index.

Keywords: Peronema canescens, Antiplasmodial activity, MTT method, Selectivity index, Cytotoxicity index, Plasmodium falciparum

(c) 2018 The Authors. Published by Innovare Academic Sciences Pvt Ltd. This is an open-access article under the CC BY license (http://creativecommons.org/licenses/by/4.0/) DOI: http://dx.doi.org/10.22159/ijpps.2018v10i10.25124

\section{INTRODUCTION}

Malaria is an endemic disease in Indonesia: in 2016, the annual parasite incidence (API) was 0,77 per 1000 population. Plasmodium falciparum, one of the pathogens responsible for this disease. The drug of choice for malaria treatment is artemisinin-based combination therapy (ACT). However, the latest studies have shown a gene mutation in Plasmodium falciparum that is associated with a reduced response to ACT [1-5].

This new resistance to the malarial plasmodium has initiated the development of new antimalarial drugs. Plant-based medicines are viewed as one of the alternative sources of new antimalarials. In Indonesia, a number of different plants have been studied for their antimalarial properties, including papaya leaves (Carica papaya Linn), mahogany fruit (Swietenia mahagoni Jacq.), neem leaves (Azadirachta indica Juss.), pule seeds (Alstonia scolaris), meniran herb (Phyllanthus niruri L.), Mundus bark (Garcinia dulcis Roxb.), Carthamus tinctorius Linn. flowers, Artocarpus sp. and sambiloto (Andrographis paniculata) [6-12]. One plant that has been used empirically as an antimalarial in some communities in southern Sumatera is sungkai (Peronema canescens), although research on its antiplasmodial activity is still limited. One previous study reported that a sungkai leaf extract showed in vivo antiplasmodial activity in Swiss mice [13]. Other studies published in 2004 and 2005 showed that sungkai leaf extracts had in vitro antibabesia activity $[8,14]$.

Natural ingredients, like those in sungkai leaf extracts, should go through thorough testing, prior to their use as drugs, to assess their activity as well as their toxicity. Thus far, sungkai leaf extracts have undergone only limited testing; therefore, the aim of the present study was to assess the activity and toxicity of various extracts of sungkai leaves prepared using solvents with different polarities. We investigated the antiplasmodial and toxicity activities and evaluated the selectivity or cytotoxicity indices of acetone, ethanol and aqueous extracts of Peronema canescens leaves.

\section{MATERIALS AND METHODS}

\section{Chemicals and reagents}

Acetone, ethanol and distilled water, RPMI 1640 (Sigma-Aldrich, St. Louis MO, USA) supplemented with 25 mmol HEPES (Sigma) and 30 mmol $\mathrm{NaHCO}_{3}$, gentamicin, human erythrocytes (O blood type), human serum (O blood type), sorbitol, Giemsa solution, M199 (Sigma) medium with $10 \%$ foetal bovine serum and $0.5-1 \%$ fungizon, thiazolyl blue tetrazolium bromide (MTT $=3-(4,5$ dimethylthiazol-2-yl)-2,5-diphenyl tetrazolium bromide) (Sigma), sodium dodecyl sulphate (SDS) (Sigma) in $0.01 \mathrm{M} \mathrm{HCl}$.

\section{Plant materials and extracts}

Leaves were collected from Peronema canescens plants growing in their natural habitat in the Lahat and Empat Lawang Districts, South Sumatra Province, Indonesia. The location coordinates where the specimens of Peronema canescens leaves were growing were 3 ${ }^{\circ} 42^{\prime} 6.15^{\prime \prime S}-103{ }^{\circ} 19^{\prime} 10.43 " \mathrm{E}$ and $3^{\circ} 37^{\prime} 23.14$ "S-103 ${ }^{\circ} 3^{\prime} 36.31$ "E. The plant was identified at the Pharmacognocy Laboratory, Department of Pharmaceutical Biology, Faculty of Pharmacy, Gadjah Mada University, Yogyakarta with number UGM/FA/166/Ident/XII/2006.

The Peronema canescens leaves were air dried and ground to a fine powder. A percolation method was used to obtain the Peronema canescens leaf extracts from the leaf powder using acetone, ethanol and distilled water solvent. The powder was first percolated with acetone and obtain the acetone extract. The residue from the acetone extract was then percolated with absolute ethanol to obtain the ethanol extract. The residue from the ethanol extract was then percolated with distilled water to obtain the aqueous extract. The 
filtrates were concentrated with a rotary evaporator to generate the final acetone, ethanol and aqueous extracts $[15,16]$.

\section{In vitro cultivation of Plasmodium falciparum}

Plasmodium falciparum strains D10 and FCR3 were obtained from continuous cultures at the Parasitology Laboratory, Department of Parasitology, Faculty of Medicine, Public Health and Nursing, Gadjah Mada University. Both strains were cultured according to Trager and Jensen $[17,18]$ and were maintained in vitro in human erythrocytes (O blood type) with a $1 \%$ haematocrit in RPMI 1640 (Sigma) supplemented with $25 \mathrm{mmol}$ HEPES (Sigma) and $30 \mathrm{mmol} \mathrm{NaHCO}{ }_{3}$. Gentamicin at $25 \mathrm{mg} / \mathrm{l}$ and $10 \%$ human serum (O blood type) were also added, and the parasite cultures were incubated at $37^{\circ} \mathrm{C}$ in candle jars. The media were changed every day. The parasite cultures were synchronised with $5 \%$ sorbitol, as described by Lambros and Vanderberg $[9,16,18]$.

\section{In vitro antiplasmodial activity}

In vitro antiplasmodial activity was tested in the parasitology laboratory, Faculty of Medicine, Public Health and Nursing, Gadjah Mada University using 96-well microplates. The ring stage of the Plasmodium falciparum cultures with $2 \%$ parasitaemia and $3 \%$ haematocrit was used in this test, and the tests were performed three times for each sample (triplicate). A total of $100 \mu \mathrm{l}$ of parasite culture and $100 \mu \mathrm{l}$ of leaf extract in the culture medium were distributed into each well of the microplate. The leaf extracts were supplied at varying concentrations. The parasite and extract mixtures were incubated for $72 \mathrm{~h}$ at $37^{\circ} \mathrm{C}$ in the candle jar. Parasitaemia was calculated after incubation by counting the parasite numbers in thin smears. The parasite growth inhibition was expressed as a percentage of the negative control. The antiplasmodial activity was determined by calculating the $\mathrm{IC}_{50}[9,16]$.

\section{Cytotoxicity activity}

In vitro cytotoxicity activity tests were also conducted at the parasitology laboratory, Faculty of Medicine, Public Health and Nursing, Gadjah Mada University. The Vero cells used in this study were obtained from the continuous culture at Parasitology
Laboratory, Department of Parasitology, Faculty of Medicine, Public Health and Nursing, Gadjah Mada University. The cells were cultured in M199 (Sigma) medium with 10\% foetal bovine serum and 0.5-1\% fungizon at $37{ }^{\circ} \mathrm{C}$ and $5 \% \mathrm{CO}_{2}$. The Kasugai method, with some modification, was used to measure cytotoxicity [19]. A $1 \mu \mathrm{l}$ volume containing of $1 \times 10^{4}$ Vero cells in culture medium was distributed into a 96-well plate and incubated for $24 \mathrm{~h}$ at $37{ }^{\circ} \mathrm{C}, 5 \% \mathrm{CO}_{2}$. A 100 $\mu \mathrm{l}$ volume of leaf extract at various concentrations in culture medium was then added and incubated for a further $72 \mathrm{~h}$ at $37^{\circ} \mathrm{C}$, $5 \% \mathrm{CO}_{2}$. The culture medium was then collected with a micropipette, and $100 \mu \mathrm{l}$ was mixed with $10 \mu \mathrm{l}$ MTT solution (Sigma) and incubated for $4 \mathrm{~h}$ at $37^{\circ} \mathrm{C}, 5 \% \mathrm{CO}_{2}$. A $100 \mu \mathrm{l}$ volume of $10 \%$ SDS in $0.01 \mathrm{M} \mathrm{HCl}$ was added to dilute the formazan and incubate for 18 $\mathrm{h}$ at room temperature. The absorbance was read with an ELISA reader at $595 \mathrm{~nm}$. The $\mathrm{IC}_{50}$ values was calculating with probity analysis $[9,16,19]$.

\section{Statistical analysis}

The antiplasmodial and cytotoxicity activities of the three extracts tested were compared using one-way ANOVA. The $\mathrm{IC}_{50}$ values were determined using probit analysis.

\section{RESULTS}

\section{In vitro antiplasmodial activity}

The highest concentrations of the acetone, ethanol and aqueous extracts inhibited the growth of Plasmodium falciparum strain D10 by $85.25 \pm 2.43 \% ; 82.38 \pm 4.24 \%$ and $87.32 \pm 2.77 \%$ after a 72 $\mathrm{h}$ incubation, as shown in fig. 1 . The mean $\mathrm{IC}_{50}$ values for the acetone, ethanol and aqueous extracts were $26.33 \pm 1.65$, $37.96 \pm 8.17$ and $12.26 \pm 1.05 \mu \mathrm{g} / \mathrm{ml}$, respectively. The ANOVA test $(p=0.05)$ for the D10 strain revealed a significant difference between the three extracts $(p=0.00)$. Post-hoc test results showed significant differences between the acetone and aqueous extracts $(p=0.03)$ and between the ethanol and aqueous extracts $(p=0.01)$, but no significant differences between the acetone and ethanol extracts $(\mathrm{p}=0.06)$ in terms of their ability to inhibit the growth of the D10 strain.

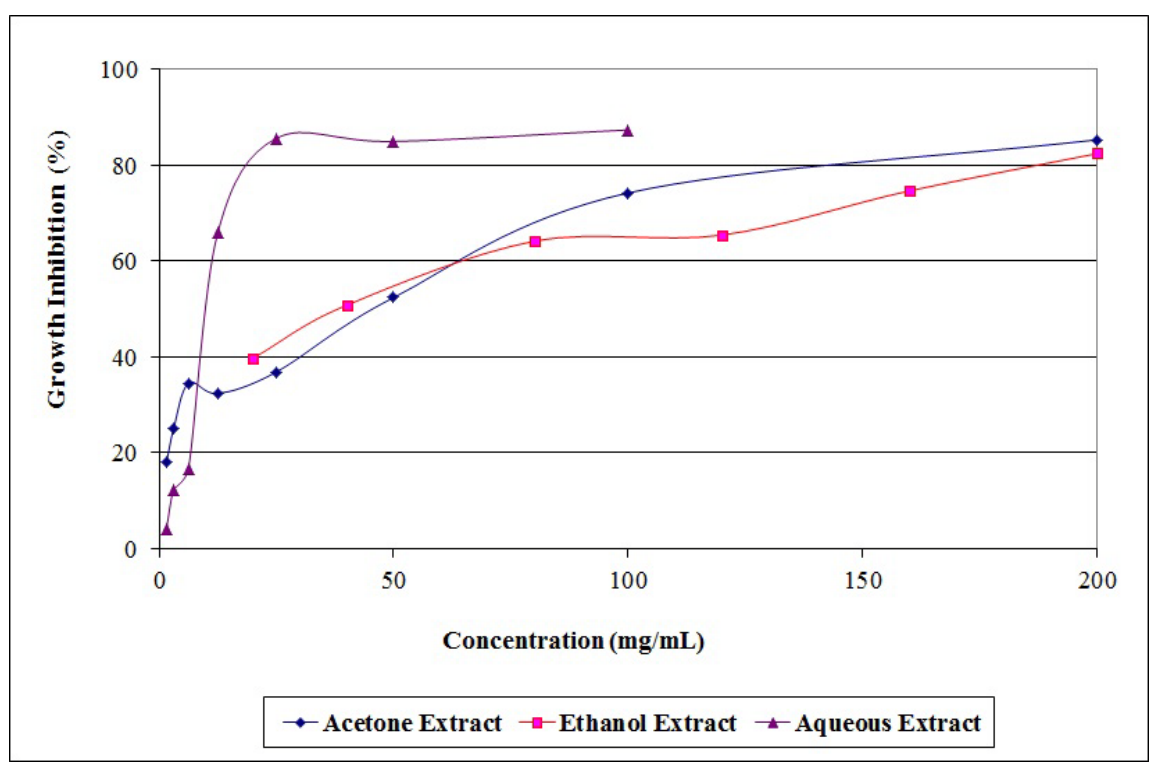

Fig. 1: Percentage of growth inhibition of Plasmodium falciparum strain D10 after incubation of Peronema canescens leaves extract for 72 h. *Tests were performed for 6-8 concentration levels and 3 replications for each sample

The highest concentrations of the acetone, ethanol and aqueous extracts inhibited the growth of the FCR3 strain by $90.51 \pm 2.32 \%$, $92.76 \pm 0.43 \%$ and $69.60 \pm 1.21 \%$, respectively, after a $72 \mathrm{~h}$ incubation, as shown in fig. 2 . The mean $\mathrm{IC}_{50}$ values for the acetone, ethanol and aqueous extracts were $51.14 \pm 8.65,70.22 \pm 14.13$ and $34.85 \pm 6.04 \mu \mathrm{g} / \mathrm{ml}$, respectively. The ANOVA test $(\mathrm{p}=0.05)$ for the
FCR3 revealed a significant difference between the three extracts ( $\mathrm{p}$ $=0.00$ ). Post-hoc test results showed significant differences between the ethanol and aqueous extracts $(p=0.01)$, but no significant differences between the acetone and ethanol extracts $(p=0.15)$ or between the acetone and aqueous extracts $(p=0.24)$ in terms of their ability to inhibit the growth of the FCR3 strain. 


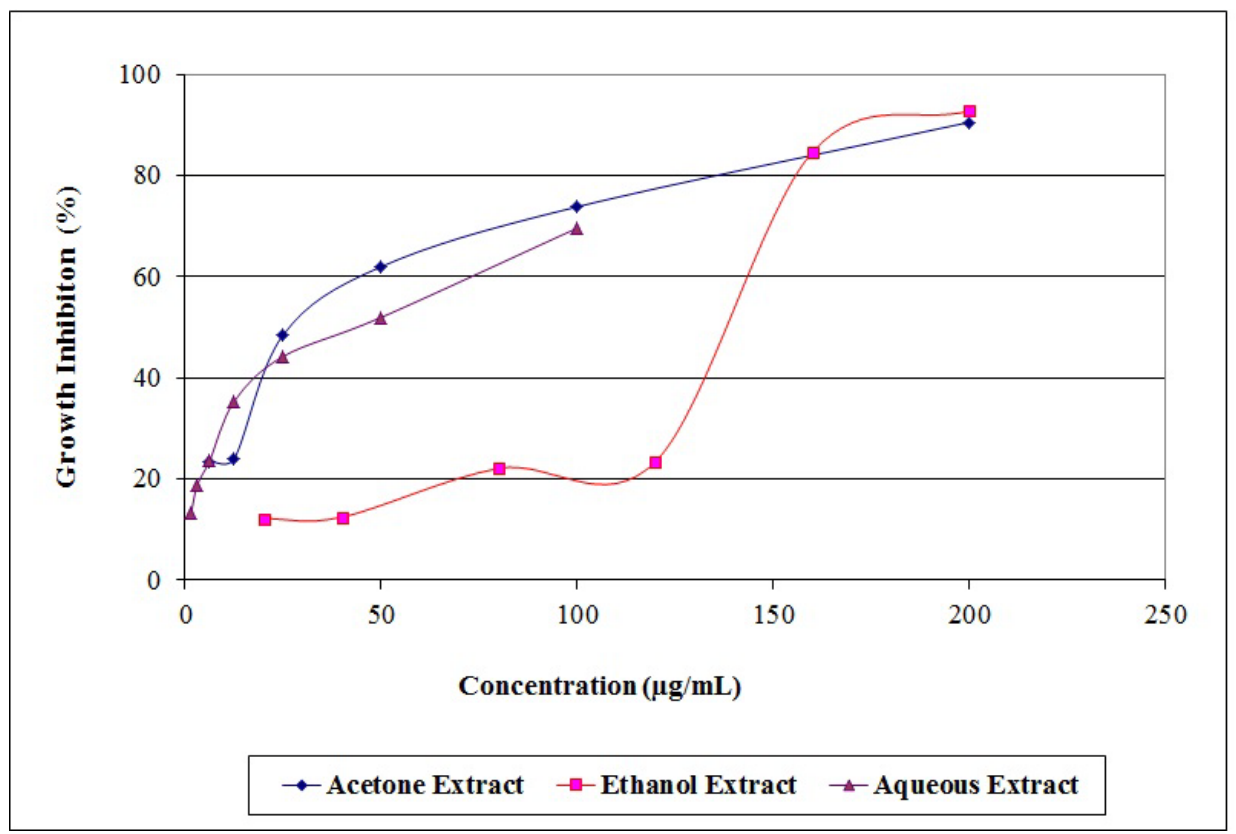

Fig. 2: Percentage of growth inhibition of Plasmodium falciparum strain FCR3 after incubation of Peronema canescens leaves extract for $72 \mathrm{~h}$. *Tests were performed for 6-8 concentration levels and 3 replications for each sample

The IC $_{50}$ values for Plasmodium falciparum strains D10 and FCR3 indicated that the Peronema canescens leaf extracts were more effective against Plasmodium falciparum strain D10 than against Plasmodium falciparum strain FCR3 (table 1).

Table 1: Antiplasmodial activity ( $\mathrm{IC}_{50}$ in $\mu \mathrm{g} / \mathrm{ml}$ ), cytotoxicity activity $\left(\mathrm{IC}_{50} \mathrm{in} \mu \mathrm{g} / \mathrm{ml}\right.$ ) and Selectivity Index of Peronema canescens leaves extract against Plasmodium falciparum D10 and FCR3 strains and vero cell at $72 \mathrm{~h}$ Incubation

\begin{tabular}{lllll}
\hline Extract & Vero Cell*) $^{*}$ & $\begin{array}{l}\text { Plasmodium falciparum D10 } \\
\text { strain*) }\end{array}$ & Selectivity index & $\begin{array}{l}\text { Plasmodium falciparum FCR3 } \\
\text { strain*) }\end{array}$ \\
\hline Acetone & $23.37 \pm 5.63$ & $26.33 \pm 1.65$ & 0.89 & $51.14 \pm 8.65$ \\
Ethanol & $629.46 \pm 24.85$ & $37.96 \pm 8.17$ & 16.46 & $70.22 \pm 14.13$ \\
Aqueous & $634.00 \pm 144.82$ & $12.26 \pm 1.05$ & 51.70 & $34.85 \pm 6.04$ \\
\hline
\end{tabular}

${ }^{*}$ mean \pm SD, ${ }^{* *}$ Tests were performed for 6-8 concentration levels and 3 replications for each sample

\section{Cytotoxicity activity}

The acetone extract at the highest concentration $(400 \mu \mathrm{g} / \mathrm{ml})$ was highly cytotoxic, causing the death of $98.26 \pm 0.67 \%$ of the Vero cells. Concentrations of $200 \mu \mathrm{g} / \mathrm{ml}$ caused the death of $99.10 \pm 1.56 \%$ of the cells. By contrast, the ethanol and aqueous extracts, at the same highest concentration $(400 \mu \mathrm{g} / \mathrm{ml})$ resulted in the death of only $11.34 \pm 6.38 \%$ and $8.69 \pm 6.32 \%$ of the Vero cells, respectively. The $\mathrm{IC}_{50}$ values for the acetone, ethanol and aqueous extracts were $23.37 \pm 5.63$, $629.46 \pm 24.85$ and $634.00 \pm 144.82 \mu \mathrm{g} / \mathrm{ml}$, respectively (table 1). Statistical analysis using ANOVA $(\mathrm{p}=0.05)$ revealed a significant difference between the three extracts $(p=0.00)$.

\section{Selectivity index}

The level of drug toxicity can be compared to its activity based on the selectivity index or the cytotoxicity index. In this study, the selectivity index was calculated by comparing the $\mathrm{IC}_{50}$ value from the cytotoxicity test and the $\mathrm{IC}_{50}$ of the test activity at $72 \mathrm{~h}$ of incubation. The selectivity index values are shown in table 1.

\section{DISCUSSION}

The $\mathrm{IC}_{50}$ values for the different Peronema canescens leaf extracts can be grouped according to the criteria of the observed antiplasmodial activity for herbal extracts [20-22]. Based on these criteria, all Peronema canescens leaf extracts had good antiplasmodial activity against Plasmodium falciparum strain D10. However, the activity against Plasmodium falciparum strain FCR3 was only evident with the aqueous extract, as the acetone and ethanol extracts showed poor antiplasmodial activity. Therefore, aqueous leaf extracts are likely to show better antiplasmodial activity overall when compared to acetone and ethanol extracts.

Previous research on Peronema canescens has indicated that acetone extracts have antiplasmodial activity against Plasmodium falciparum strain $\mathrm{K} 1$, and that this activity may be due to the presence of 7clerodane diterpenoid peronemins found in the acetone extracts. Six of these compounds have been tested and two, peronemin C1 and peronemin B1, had antiplasmodial activity. The $\mathrm{IC}_{50}$ value of peronemin $\mathrm{C} 1$ was $13.1 \mu \mathrm{M}(5.03 \mu \mathrm{g} / \mathrm{ml})$, and peronemin $\mathrm{B} 1$ at a dose of $118 \mu \mathrm{M}(43 \mu \mathrm{g} / \mathrm{ml})$ could inhibit plasmodial growth by as much as $83 \%$ [23]. The difference between these results and those of the present study may reflect differences in the tested strains of Plasmodium falciparum. For example, the $P$ falciparum D10 strain was less sensitive to the acetone and ethanol extracts, but these extracts still had some antiplasmodial activity.

Aqueous extracts have also been reported previously to have antiplasmodial activity. A study on Vernonia cinerea identified the antiplasmodial compound in an aqueous extract as a sesquiterpene lactone [24]. Other research on Peronema canescens leaves indicated that an aqueous extract had in vitro activity against Babesia gibsoni, with an $\mathrm{IC}_{50}$ value of $43.8 \pm 3.5 \mu \mathrm{g} / \mathrm{ml}$ [14]. Other research has also indicated that aqueous extracts from various plants show antibacterial and antiplasmodial activity [8].

The antiplasmodial activity of a natural product has to be balanced by low cytotoxicity. In the present study, an $\mathrm{IC}_{50}>30 \mu \mathrm{g} / \mathrm{ml}$ was considered to indicate low toxicity and an $\mathrm{IC}_{50}$ of $20-30 \mu \mathrm{g} / \mathrm{ml}$ was considered to indicated moderate cytotoxicity [21]. Based on this 
categorization, the acetone extract has moderate cytotoxicity, and the ethanol and aqueous extracts have low cytotoxicity. The post-hoc test indicated that the acetone extract is more toxic than the aqueous and ethanol extracts, while the aqueous and ethanol extracts have almost the same cytotoxicity. Research on the cytotoxicity of sungkai leaf extracts has not been widely reported, although one in vivo toxicity test of a Peronema canescens extract found that no mice that died after the test [14]. Another study on Peronema canescens leaves showed that a methanol extract and an $\mathrm{N}$-hexane fraction of Peronema canescens leaves gave $\mathrm{LC}_{50}$ values of 387.257 and 107.399 $\mu \mathrm{g} / \mathrm{ml}$, respectively, against shrimp larvae [25].

Any drug used to treat parasite infections must be selective and only inhibit the biological processes essential to parasite development without affecting the host. The selectivity index, which is the ratio of the $\mathrm{IC}_{50}$ for cytotoxicity over the IC $\mathrm{I}_{50}$ for antiplasmodial activity, is a useful parameter for determining the selectivity of the three extracts. A selectivity index ratio of less than 10 indicates a non-selective drug [21]. The selectivity index for the acetone extract indicated that it is not selective, whereas the ethanol and aqueous extracts are selective. The aqueous extract of Peronema canescens leaves would appear to be a better choice for development as an antimalarial drug because it had the best antiplasmodial activity and the best selectivity. These results of this study differ from those previously published, which suggested that peronemins isolated from acetone extracts have antiplasmodial activity [23]. In the present study, the acetone extract had good antiplasmodial activity but was highly toxic. An antiplasmodial should have good selectivity for the parasitic cells without harming the host cells. Another study has also reported that an ethanol extract has antiplasmodial activity against mice infected with Plasmodium berghei [13]. In the present study, the ethanol extract had the lowest antiplasmodial activity when compared with the other two extracts, although its toxicity was also low. The results of the present study are in line with the habits of people who currently use decoctions of Peronema canescens leaves to treat malaria and fever.

\section{CONCLUSION}

The aqueous extract of Peronema canescens leaves had the highest in vitro antiplasmodial activity and the best selectivity index.

\section{ACKNOWLEDGMENT}

We gratefully acknowledge the volunteers who were willing to donate blood (RBC and serum) to foster a culture of Plasmodium falciparum. We also thank the lecturer staff, laboratory staff, technicians, non-teaching staff and administration staff of Department of Parasitology, Faculty of Medicine, Public Health and Nursing, Gadjah Mada University, for their enthusiastic co-operation and assistance for this research.

\section{AUTHORS CONTRIBUTIONS}

1. Conceptualization and study design-Jhons Fatriyadi Suwandi, Mahardika Agus Wijayanti, Mustofa.

2. Data collection, sample analysis and performing the experiment design-Jhons Fatriyadi Suwandi, Mahardika Agus Wijayanti, Mustofa

3. Preparation of manuscript design-Jhons Fatriyadi Suwandi

4. Statistical Analysis design-Jhons Fatriyadi Suwandi.

5. Proofreading the manuscript design-Jhons Fatriyadi Suwandi

6. All authors read and approved the final manuscript.

\section{CONFLICTS OF INTERESTS}

All authors have not conflicted of interest

\section{REFERENCES}

1. Ministry of Health of the Republic of Indonesia. Indonesia health profile year 2008. Jakarta: Ministry of Health of the Republic of Indonesia; 2009.

2. Ministry of Health of the Republic of Indonesia. Guidelines for managing malaria cases in Indonesia. Jakarta: Directorate General of Disease Control and Environmental Health; 2011.
3. Suwandi JF. Polymorphism of PfMDR1 and PfATP6 genes from malaria falciparum patients at Pesawaran District. Yogyakarta: Universitas Gadjah Mada; 2014.

4. Ministry of Health of the Republic of Indonesia. Indonesia health profile year 2013: Jakarta: Ministry of Health Republic of Indonesia; 2014.

5. Pusat Data dan Informasi Kementerian Kesehatan RI, Data dan Informasi Propil Kesehatan Indonesia 2016. Jakarta: Kementerian Kesehatan Republik Indonesia; 2017.

6. Tjokrosonto S. Sensitivity of Alstonia Scholaris (Pule) stem bark to malaria parasites (Plasmodium falciparum). Yogyakarta: Universitas Gadjah Mada; 1992.

7. Akrom. Effect of meniran herbs ethanol extract (Phyllanthus niruri L) against the cellular immune response of Swiss mice infected by Plasmodium berghei: a study of phytochemical immunomodulatory. Yogyakarta: Universitas Gadjah Mada; 2004.

8. Murningsih T, Subeki, Matsuura H, Takahashi K, Yamasaki M, Yamato 0 , et al. Evaluation of inhibitory activities of the extracts of indoneisan traditional medical plants against Plasmodium falciparum and Babesia gibsoni. J Vet Med Sci 2005;67:829-31.

9. Mustofa, Sholikhah EN, Wahyuono S. In vitro and in vivo antiplasmodial activity and cytotoxicity of extracts of Phyllanthus niruri L. herbs traditionally used to treat malaria in Indonesia. Southeast Asian J Trop Med Public Health 2007;38:609-15.

10. Hafid AF, Septiani RP, Fabriana LH, Febrianty N, Ranggaditya D, Widyawaruyanti A. Antimalarial activity of crude extracts of Artocarpus heterophyllus, Artocarpus altilis, and Artocarpus camansi. Asian J Pharm Clin Res 2016;9:261-3.

11. Rahayu MP, Harmastuti N, Pamudji G, Klodengan DR, Supargiyono, Wijayanti MA. In vivo test of antimalarial activity from dichloromethane-ethyl acetate-methanol fractions of mundu's bark (Garcinia dulcis (Roxb.) in swiss webster mice. Asian J Pharm Clin Res 2017;50(Spesial Issue):1-3.

12. Putra AMJ, Chaidir C, Hanafi M, Yanuar A. Predicted binding mode of andrographolide and its derivatives bound to Plasmodium falciparum geranylgeranyl pyrophosphate synthase. Int J Appl Pharm 2017;9(Special Issue October):94-7.

13. Dewi S. Preliminary test of sungkai leaf ethanol extract (Peronema canescens Jack) on Plasmodium berghei (ANKA) growth in swiss strain mice. Padang: Universitas Andalas; 1995.

14. Subeki, Matsuura H, Yamasaki M, Yamato O, Maede Y, Katakura $\mathrm{K}$, et al. Effects of Central Kalimantan plant extracts on intraerythrocytic Babesia gibsoni in culture. J Vet Med Sci 2004;66:871-4.

15. Directorate General of Food and Drug Administration of the Ministry of Health of the Republic of Indonesia. A galenician. Jakarta: Ministry of Health of the Republic of Indonesia; 1986.

16. Suwandi JF. Antiplasmodial activity of sungkai leaf extract (Peronema canescens): study of in vitro and in vivo antiplasmodium activity, hem polymerization inhibition activity and cytotoxic activity on vero cells. Yogyakarta: Universitas Gadjah Mada; 2007.

17. Trager W, Jensen JB. Human malaria parasites in continuous culture. Science 1976;193:673-5.

18. Ljungström I, Perlmann H, Schlichtherle M, Scherf A, Wahlgren M. Methods in malaria research. 4th ed. Manassas: MR4/ATCC; 2004.

19. Kasugai $\mathrm{S}$, Hasegawa N, Ogura H. A simple in vitro cytotoxicity test using the MTT $(3-(4,5)$ Tetrazolium Bromide) colorimetric assay: analysis of eugenol toxicity of dental pulp cells (RPCC2A). Japan J Pharmacol 1990;52:95-100.

20. Gessler M, Nkunya MH, Mwasumbi L, Heinrich M, Tanner M. Screening tanzanian medical plants for antimalarial activity. Acta Trop 1994;56:65-77.

21. Jenett Siems K, Mockenhaupt FP, Bienzle U, Gupta MP, Eich E. In vitro antiplasmodial activity of central American medicinal plants. Trop Med Int Health 1999;4:611-5.

22. Bickii J, Tchouyab GRF, Tchouankeub JC, Tsamob E. Antimalarial activity in crude extracts of some Cameroonian medicinal plants. Afr J Tradit Complement Altern Med 2007;4:107-11. 
23. Kitagawa I, Simanjuntak P, Hori K, Nagami N, Mahmud T, Shibuya $\mathrm{H}$, et al. Indonesian medical plant. VII. Seven new clerodane-type diterpenoids, Peronemins A2, A3, B1, B2, B3, C1, and D1, from the leaves of Peronema canescens (Verbenaceae). Chem Pharm Bull 1994;42:1050-5.
24. Chea A, Hout S, Long C, Marcourt L, Faure R, Azas N, et al. Antimalarial activity of sesquiterpene lactones from Vernonia cinerea. Chem Pharm Bull 2006;54:1437-9.

25. Ahmad I, Ibrahim A. Bioactivity methanol extract and N-Hexane fraction of sungkai leaf (Peronema canescens Jack) against shrimp larvae (Artemia salina Leach). J Sains Kes 2015;1:114-9. 